\title{
Confrontation in Paris
}

\author{
from our Special Correspondent
}

A Poliey for science is an elusive thing, not to be pursued by those who hope for quick and easy answers. But this seems not to have deterred the members of the Committee for Science Policy of the Organization for Economic Co-operation and Development, who met in Paris last week. The committee gathercd to hear the last stage in the examination which the OECD has made of the science policy of the United States. The meeting was a confrontation between the examiners who have been responsible for the report, and delegates from the United States who know at first hand how science is organized in the United States.

The party from the United States was led by $\mathrm{Dr}$ Donald Hornig, President Johnson's Special Assistant for Science and Technology. He was accompanied by Dr Ivan Bennet, Deputy Director of the Office of Science and Technology; $\mathrm{Mr}$ Herman Pollack, Director of International Scientific and Technological Affairs, Depart. ment of State; Dr Philip Handler, Chairman of the National Science Board; Congressman George P. Miller, Chairman of the Committee of Science and Astronautics of the US Congress; Mr William Carey, Assistant Director, Bureau of the Budget; and Mr James A. Shannon, Director of the National Institutes of Health.

The report itself falls into two sections. The first, prepared by the examiners, consists of four ossays written from an individual point of view. The second section, prepared by the secretariat, backs up these rather sub. jective views with some statistical data. This is necessary because of the way in which the examiners carried out their survey-a ten day visit to the United States, packed with interviews at every turn, may capture the flavour, but cannot include all the facts. The examiners' reports should not therefore be expected be to correct in every particular, nor to agree on every point.

The confrontation meeting at the Chateau de la Mouette in Paris covered four broad areas. The first, science policy proper, was concerned with the institutions, the problems of defining priorities, the role of Congress, the dangers of the "military-industrial complex", and the integration of science into forcign policy. The second arca of discussion covered the impact of science policy on academic research. One question asked, for example, was whether the efforts being made to produce more qualified manpower could ever be successful. Was there not a danger that increasing the output of qualified people would itself have a multiplying effect which would create a demand for more poople than could possibly be supplied ? In the third and fourth areas of discussion, science policy and industry, problems such as the distribution of federal expenditure between firms, and the extent to which prosperity in some areas of industrial life relies on federal support. were discussed. Professor Casimir raised the problem of the amount of spin-off which derives from large research projects. Did one have to have a space programme to get the industrial benefits? In the US, ho said, companies tended to say that the effect of spin-off was negligible, while federal agencies said that the importance of spin-off could not be over-estimated. Dr Hornig said that it was hard to reach the truth by polling industry, which tended to oppose large scale federal rosearch and development. The identifiable dircct spin-off was small, he said, but the indirect, effects were considerable.

M. Pierre Massé went on to discuss the ways in which federally supported science could be brought to bear on social problems. Dr Hornig started his reply by saying that there was no problem in finding places for social scientists -lawyors already filled Congress, and economists had an important place in the US. And large scale social problems were not as new to the United States as Europeans sometimes implied-there was Social Security and the New Deal in the thirties, for example. But one of the difficulties was deciding what should be done-in the cities, for example, half the social scientists thought that the problems could be solved by increasing population density, while the other half thought that it was too high already. Technology alone could not solve problems as complicated as this, though it could help. Mr Carey added that they were relying heavily on faith and hopo in turning to the social scientists - it was not yet clear how they could help, although they were eager to.

M. Pierre Massé brought the discussion round to the problem of the technology gap. The rapid advance of technology had introduced a de-stabilizing effect into international trade relations, and there was a danger that if the US economy became too dominating, it would invite repercussions from Europe. Did the United States feel that it was part of its duty to make sure that this did not happen? In the short term, would it not be in the United States interest to support schemes of industrial good-neighbourliness, to enable Europe to eatch up? Dr Hornig thought that schemes of this sort were not really necessary - "the process of catching up is always easicr than the process of getting away". Japan was a living example of this. Not only were the differences of wage rates a stabilizing influence, but the rapid flow of technological information also tended to even things up. Dr Hornig's recipe was that international relations should be stimulated by competition, mitigated by the effects of the transfer of information and by co-operation on some projects.

All this was useful discussion, if at times rather imprecisely articulated. What did emerge was at least somo reassurance to the Europeans-the United States has not achieved its pre-eminence in science and technology by organizing it in a fundamentally more efficient way. There are, of course, occasional felicities of organization which could be transplanted with advantage to Europe, although a number of them would require a more united Europe if they were to be applied with any hope of success. But if the fact that the United States administration has not hit upon some uniquely happy form of organization is a reassurance to some European governments, it also means that American experience is unlikely to supply any short cuts to success.

The short lesson, although the United States witnesses were far too tactful to put it this way, was that Europe should concentrate in putting its own house in order. United States success should be seen as a spur to European suceess, not as a daunting reminder of failure. And observers were left with soveral clear impressions of the way in which Europe could set about the task. The principal need, it is probably fair to say, is for far more genuine collaboration in Europe-the formation of European learned societies would be a worthwhile start. On the industrial front, the Eeonomic Community should make sure that its organization provides for effective industrial mergers within Europe, instead of making it easy for United States companios to pick off European companies by lightning sorties with cheque book in hand. 